\title{
KELEMAHAN PEMERINTAH DESA DALAM MUSYAWARAH PERENCANAAN PEMBANGUNAN (MUSREMBANG) DI DESA TONRONGNGE KECAMATAN BARANTI KABUPATEN SIDENRENG RAPPANG
}

\author{
Oleh \\ Via Aulia Ratri (43182071) \\ Mahasiswi Universitas Muhammadiyah Sidereng Rappang \\ Fakultas Ilmu Sosial Dan Ilmu Politik \\ Prodi Administrasi Publik \\ Email : viaauliaratri@gmail.com
}

\begin{abstract}
The purpose of this study was to analyze the weaknesses of the village government in the Development Planning Deliberation (Musrembang) in Tonrongnge Village, Baranti District, Sidenreng Rappang Regency. This study uses a qualitative method, namely the study of literature. This technique is done by reading, studying and reviewing the literature related to the Village Government in the Development Planning Deliberation (Musrembang). The results of the study indicate that there are many weaknesses of the village government in the Development Planning Deliberation forum. One of them is the policy that is planned in the development planning deliberation process has not been right on target. This is known because the results of the annual development planning deliberations have not been realized. So that the output of the policy has not been felt by the public. This can happen because of a lack of understanding in identifying a problem that exists in the environment according to what the community needs.
\end{abstract}

Keywords : village government, development planning, Musrembang

\begin{abstract}
Abstrak
Tujuan penelitian ini untuk menganalisis kelemahan-kelemahan pemerintah desa dalam Musyawarah Perencanaan Pembangunan (Musrembang) di Desa Tonrongnge Kecamatan Baranti Kabupaten Sidenreng Rappang. Penelitian ini menggunakan metode kualitatif yaitu studi literatur. Teknik ini dilakukan dengan cara membaca, mempelajari dan mengkaji literatur-literatur yang berhubungan dengan Pemerintah Desa dalam dalam Musyawarah Perencanaan Pembangunan (Musrembang). Hasil penelitian menunjukkan bahwa terdapat banyak kelemahan-kelemahan dari pemerintah desa dalam forum Musyawarah Perencanaan Pembangunan. Salah satunya adalah Kebijakan yang direncanakan dalam proses musyawarah perencanaan pembangunan belum tepat sasaran. Hal ini diketahui karena hasil dari musyawarah perencanaan pembangunan setiap tahunnya tidak terealisasi. Sehingga output kebijakan belum dirasakan masyarakat. Hal ini dapat di terjadi karena kurangnya pemahaman dalam mengidentifikasi suatu permasalahan yang ada dilingkungan sesuai dengan apa yang masyarakat butuhkan.
\end{abstract}

Kata Kunci: Pemerintah Desa, Musrembang 


\section{PENDAHULUAN}

Sebagai pionir dalam sistem pemerintahan daerah, pemerintah desa akan bersentuhan langsung dengan masyarakat. Oleh karena itu, sistem dan mekanisme pengelolaan pemerintah daerah sangat didukung dan diputuskan oleh pemerintah desa. Struktur kelembagaan dan mekanisme kerja pemerintah di semua tingkatan, terutama pemerintah tingkat desa, harus diarahkan untuk membentuk pemerintahan yang peka terhadap perkembangan dan perubahan social .

Pemerintah desa sebagai ujung tombak dalam sistem pemerintahan daerah akan berhubungan dan bersentuhan langsung dengan masyarakat. Karena itu, sistem dan mekanisme penyelenggaraan pemerintahan daerah sangat didukung dan ditentukan oleh pemerintah desa. Struktur kelembagaan dan mekanisme kerja di semua tingkat pemerintah, khususnya pemerintahan desa harus diarahkan untuk dapat menciptakan pemerintahan yang peka terhadap perkembangan dan perubahan yang terjadi dalam masyarakat.

Dalam Undang-undang Nomor 6 tahun 2014 tentang Desa, dijelaskan bahwa Pemerintah Desa dan masyarakat desa bersama-sama melaksanakan pendekatan untuk 'membangun desa' dan dengan semangat gotong royong serta memanfaatkan kearifan lokal dan sumber daya alam desa yang ada demi tercapainya peningkatan kesejahteraan masyarakat desa dan kualitas hidup manusia. Disamping itu, masyarakat yang semakin kritis dan semakin kompleks permasalahannya membutuhkan pelayanan yang semakin baik, terarah, terpadu dan yang terpenting adalah bagaimana memberdayakan masyarakat dengan segala potensi dan permasalahan yang dihadapinya (Mustanir \& Yasin, 2018).

Perencanaan pembangunan sendiri merupakan sebuah proses pengembangan kapasitas masyarakat dalam jangka panjang sehingga memerlukan perencanaan yang tepat dan akurat. Perencanaan ini berarti harus mampu mencakup kapan, di mana dan bagaimana pembangunan harus dilakukan agar mampu merangsang pertumbuhan ekonomi dan sosial masyarakat secara berkesinambungan.

Musyawarah Perencanaan dan Pembangunan (Musrenbang) pada hakikatnya adalah forum perencanaan pembangunan formal yang berusaha mempertemukan aspirasi masyarakat dari bawah dengan usulan program pembangunan dari instansi pemerintah. Musrenbang tercantum dalam beberapa undang-undang dan perda terkait dengan perencanaan pembangunan daerah. Musrenbang merupakan wahana publik yang penting untuk membawa para pemangku kepentingan memahami isu-isu dan permasalahan-permasalahan untuk mencapai kesepakatan atas prioritas pembangunan, dan konsesus untuk pemecahan berbagai masalah pembangunan. Musrenbang juga merupakan wahana untuk mensinkronisasikan pendekatan "top Down" dengan "bottom up" pendekatan penilaian kebutuhan masyarakat dengan penilaian yang bersifat teknis, resolusi konflik atas berbagai kepentingan pemerintah dan diluar pemerintah untuk pembangunan daerah, antara kebutuhan program pembangunan dengan kemampuan dan kendala pendanaan, dan wahana untuk mensinergikan berbagai sumber pendanaan pembangunan (Hatta, 2014).

Penyelenggaraan Musrenbang wajib diselenggarakan menurut UU.No 6 Tahun 2014 tentang Desa karena hasil dari kegiatan Musrenbang akan memperoleh informasi paling penting terhadap usulan program yang di prioritaskan dari masyarakat karena apa yang dihasilkan merupakan kebutuhan masyarakat yang sebenarnya. 
Dalam proses kegiatan musrembang pasti tidak akan selalu berjalan dengan lancar, Akan ada saja kelemahan-kelemahan didalam prosesnya. Dari hasil observasi yang diamati, ditinjau dari segi bentuk peranan aparatur pemerintah desa yakni tugas dan fungsi dalam melaksanakan pembangunan aparatur pemerintah desa di Desa Tonrongnge Kecamatan Baranti belum optimal karena masih ada kelemehan-kelemahan dalam pelaksanaanya. maka tujuan penulisan ini adalah untuk mengatahui apa saja kelemahan musrembang dalam menghasilkan kebijakan/program yang unggul di desa Tonrongnge.

\section{KAJIAN PUSTAKA}

\section{A. Konsep Perencanan Pembangunan}

Pembangunan desa mencakup tahapan perencanaan, pelaksanaan dan pengawasan. Perencanaan pembangunan desa adalah sebuah model penggalian potensi dan gagasan pembangunan desa yang menitik beratkan pada peran serta masyarakat dalam seluruh proses pembangunan itu sendiri. Model ini dilandasi pada nilai-nilai dan gotong royong yang sudah mengakar dalam budaya masyarakat. Gotong royong berlandaskan pada keyakinan bahwa setiap warga mempunyai hak dalam memutuskan dan merencanakan apa yang terbaik bagi diri dan lingkungannya serta upaya terbaik mewujudkannya (Latif, Mustanir, et al., 2019).

Perencanaan yang menghasilkan program pembangunan yang diharapkan dapat memberikan dampak terhadap peningkatan kesejahteraan, kemakmuran dan perdamaian masyarakat dalam jangka panjang. Musrenbang dapat digunakan sebagai proses bernegosiasi, berekonsiliasi dan berharmonisasi antara pemerintah dan pemangku kepentingan non pemerintah, sekaligus mencapai konsesus bersama mengenai prioritas kegiatan pembangunan (Mustanir et al., 2019)

Arthur W. Lewis; (A. Mustanir \& Razak, 2017) mendefinisikan perencanaan pembangunan suatu kumpulan kebijaksanaan dan program pembangunan untuk merangsang masyarakat dan swasta untuk menggunakan sumber daya yang tersedia secara lebih produktif(Irwan et al., 2019)

\section{B. Pengertian Musyawarah Perencaan Pembangunan}

Musrenbang adalah forum-forum multi-pihak terbuka yang secara bersama mengidentifikasi dan menentukan prioritas kebijakan pembangunan masyarakat. Musyawarah perencanaan pembangunan (musrenbang) desa adalah forum musyawarah tahunan para pemangku kepentingan (stakeholders) desa untuk menyepakati rencana kerja desa tahun anggaran berikutnya (Mustanir \& Rusdi, 2018).

Musrenbang diselenggarakan untuk mensinkronkan berbagai kebutuhan masyarakat yang diperoleh dari forum musyawarah perencanaan pada tingkat dibawahnya sehingga menjadi suatu usulan yang terpadu untuk dilaksanakan di Desa atau dibahas kembali ke tingkat Kecamatan(Mustanir et al., 2018)

Dalam Peraturan Menteri Dalam Negeri No. 114 tahun 2014, tentang Pedoman Pembangunan Desa, yang dimaksud Perencanaan pembangunan desa adalah proses tahapan kegiatan yang diselenggarakan oleh pemerintah Desa dengan melibatkan Badan Permusyawaratan Desa (BPD) dan unsur masyarakat secara partisipatif untuk mengalokasikan dan memanfaatkan sumber daya yang 
ada dalam rangka mencapai tujuan pembangunan desa (Mustanir \& Razak, 2017).

Musrenbang merupakan wahana untuk mensinkronisasikan pendekatan "top down" dengan "bottom up" pendekatan penilaian kebutuhan masyarakat dengan penilaian yang bersifat teknis. Musrenbang adalah wahana publik yang penting untuk membawa stakeholder memahami isu isu dan permasalahan daerah mencapai Partisipasi Masyarakat Dalam Musyawarah kesepakatan atas prioritas pembangunan, dan konsesus untuk pemecahan berbagai masalah pembangunan daerah (Mustanir \& abadi, 2017).

\section{Pemerintah Desa}

Pemerintah adalah seseorang atau sekelompok orang atau suatu lingkungan kerja orang yang bersifat tetap dengan penyebutan jabatan yang menurut Surianingrat dalam (Faried, 2015) sebagai sekelompok individu yang mempunyai wewenang tertentu untuk melaksanakan kekuasaan. Kewenangan yang dimiliki oleh pemerintah tidak saja diarahan pada pemerintahan yang berdaulat dan yang tidak berdaulat. Pengertian tentang "pemerintahan" sebagaimana dirumuskan adalah suatu pengertian yang berlaku umum, namun yang paling memberikan arahan pemikiran terhadap pemerintahan sebagai studi, sebagai suatu hal yang dipelajari, dan sebagai suatu ilmu pengetahuan, bahwa pengertian tersebut sangat relevan dengan kebutuhan pemahaman terhadap pemerintahan yang berdaulat (Mustanir et al., 2020).

Pemerintahan Desa adalah penyelenggaraan urusan pemerintahan oleh pemerintah desa dan Badan Permusyawaratan Desa dalam mengatur dan mengurus kepentingan masyarakat setempat berdasarkan asal-usul dan adat istiadat setempat yang diakui dan dihormati dalam sistem Pemerintahan Negara Kesatuan Republik Indonesia (A. Mustanir and Yasin 2018) (Mustanir, Ahmad; Barisan, Barisan; Hamid 2017) .

Sedangkan menurut Widjaja (2003:3) mengungkapkan bahwa Pemerintahan Desa merupakan subsistem dari sebuah sistem penyelenggaraan pemerintah. Dengan demikian desa mempunyai kewenangan dalam mengatur kepentingan masyarakatnya. Kepala Desa akan bertanggung jawab pada BPD serta melaporkan pelaksanaannya pada Bupati (Latif, Irwan, et al., 2019).

\section{METODE PENELITIAN}

Metode penelitian ini menggunakan metode penelitian kualitatif yaitu studi literatur. studi ini bertujuan membandingkan dan menyatukan hasil-hasil temuan dari penelitian yang dilakukan dengan hasil-hasil temuan dari literature-literatur terdahulu dan untuk menentukan berbagai persamaan dan perbedaan berbagai hasil temuan yang diperoleh dari penelitian yang baru saja dilakukan (Burns \& Grove, 1993) (Afiyanti, 2014). Teknik ini dilakukan dengan cara membaca, mempelajari dan mengkaji literaturliteratur yang berhubungan dengan Pemerintah Desa dalam dalam Musyawarah Perencanaan Pembangunan (Musrembang). Dengan menggunakan studi kasus ini peneliti berharap dapat mengindentifikasi permasalahan - permasalahan yang ada di desa dalam Musyawarah Perencanaan Pembangunan (Musrembang). Lokasi penelitian ini dilakukan di Desa Tonrongnge Kecamatan Baranti Kabupaten Sidenreng Rappang, yang melaksanakan Musyawarah perencanaan pembangunan daerah ditingkat Desa. 


\section{PEMBAHASAN}

pembangunan desa akan bergerak maju, apabila tiga komponen tata pemerintahan (pemerintah, masyarakat, swasta) berperan/berfungsi. Karena itu, Musrenbang desa sebagai salah satu tugas dan kewenangan desa selaku unit otonom, merupakan proses yang penting bagi desa untuk membangun desanya sendiri. Untuk berjalannya hal ini, maka Undang Undang Pemerintah Daerah dan Undang-Undang Desa, telah mengatur perlunya Musyawarah Perencanaan Pembangunan (Musrenbang) Desa sebagai sebuah forum musyawarah tahunan para pemangku kepentingan desa untuk mengevaluasi RPJM Desa dan RKP Desa serta media untuk menyepakati Rencana Kerja Pembangunan Desa (RKPD) tahun anggaran yang direncanakan ke depan (Muluk 2007:91).

pembangunan dalam pandangan pemerintah desa dan juga masyarakat desa di Desa Tonrongnge cenderung dikonotasikan sebagai pembangunan fisik, seperti pembangunan jalan lingkungan, gorong-gorong, irigasi, sekolah, penerangan dan lainlain. Usulan usulan kegiatan masyarakat desa dalam Musrenbang desa sebagian besar menunjukan rencana pembangunan fisik di sekitarnya yang dianggap dibutuhkan untuk dibangun. Dalam pandangan masyarakat desa, keberhasilan atau kemajuan desa ditandai dengan tersedianya sarana prasarana yang baik sehingga segala aktifitas yang mereka lakukan berjalan dengan baik dan lancar. Didapati juga belum ada ketentuan mengenai jenis pembangunan fisik yang menjadi dasar usulan kegiatan dalam Musrenbang, usulan kebutuhan pembangunan fisik tersebut sangat tergantung kepada kondisi masyarakat, lingkungan dan kelengkapan sarana prasarana yang dimilikinya.

sesungguhnya fasilitas infrastruktur memiliki peran penting dalam meningkatkan kualitas hidup, kegiatan ekonomi dan bisnis. Pembangunan infrastruktur pedesaan diharapkan dapat memberikan kontribusi yang signifikan terhadap program pengentasan kemiskinan, melalui peningkatan akses masyarakat terhadap layanan dasar dan layanan sosial ekonomi, tetapi idealnya, program pembangunan Desa merupakan hasil musyawarah/rapat yang dilakukan oleh pemerintah secara bersama-sama masyarakat desa, hasilnya tentu diharapkan menjadi kebijakan/program yang memiliki tipologi spesifik dan berpihak pada kepentingan dan kebutuhan masyarakat.

Akan tetapi forum Musrenbang di desa Tonrongnge terbukti telah mengandung sejumlah kelemahan di hampir semua levelnya. Di level desa proses musrenbang mengalami distorsi dalam pelaksanaannya. Kendala utama di tingkat desa yang diidentifikasi tim peneliti, salah satunya ialah menyangkut peran pemerintah desa yang belum maksimal dalam penyusunan Musrenbang Desa.

Akibat kelemahan praktek mekanisme musrenbang tersebut maka Musrenbang Desa gagal mencapai tujuan idealnya, yakni, Pertama, untuk menampung dan menetapkan kegiatan prioritas sesuai kebutuhan masyarakat yang diperoleh dari musyawarah perencanaan pada tingkat di bawahnya (Musyawarah Dusun/kelompok). Kedua, gagal menetapkan kegiatan prioritas desa yang akan dibiayai melalui Alokasi Dana Desa yang berasal dari APBD Kabupaten/Kota maupun sumber pendanaan lainnya. Ketiga, menetapkan kegiatan prioritas yang akan diajukan untuk dibahas pada Forum Musrenbang Kecamatan (untuk dibiayai melalui APBD Kabupaten/Kota atau APBD Provinsi).

Adapun dari hasil analisis penulis beberapa kelemahan pemerintah desa dalam forum Musrembang; pertama, aspirasi masyarakat yang ditampung dalam musyawarah 
perencanaan pembangunan tidak selalu dapat direalisasikan oleh pemerintah desa. Kedua, mendominasinya skala prioritas pembangunan fisik, seperti infrastruktur pembangunan jalan penghubung antar dusun sedangkan dalam pembangunan ekonomi masih kurang. Ketiga, Partisipasi perempuan dalam proses musyawarah perencanaan pembangunan kurang dilibatkan. Hal ini dapat di sebabkan karena masih adanya anggapan bahwa dalam perencanaan pembangunan itu adalah kegiatan untuk laki-laki. Keempat, kurangnya pemahaman dalam mengidentifikasi suatu permasalahan yang ada dilingkungan sesuai dengan apa yang masyarakat butuhkan. Kelima, Kebijakan yang direncanakan dalam proses musyawarah perencanaan pembangunan belum tepat sasaran. Hal ini diketahui karena hasil dari musyawarah perencanaan pembangunan setiap tahunnya tidak terealisasi. Sehingga output kebijakan belum dirasakan masyarakat. Hal ini dapat di terjadi karena kurangnya pemahaman dalam mengidentifikasi suatu permasalahan yang ada dilingkungan sesuai dengan apa yang masyarakat butuhkan.

Adapun juga penulis mendapati beberapa titik kelemahan dari musrenbang, sehingga tidak mampu menghasilkan kebijakan/program desa yag unggul, yakni: Pertama, pada sisi mekanisme: Proses perencanaan partisipatif melalui mekanisme musrenbang masih menjadi retorika, dikarenakan aktor yang penting dan dominan dalam penyusunan formulasi perencanaan pembangunan di desa adalah pemerintah desa. Kedua, pada sisi proses: Proses Musrenbang hanya berisi kegiatan berupa paparan dari kepala desa dan perangkatnya. Peserta hanya diberikan kesempatan untuk bertanya mengenai seputar kegiatan- kegiatan tersebut, tidak ada diskusi dan negoisasi (dialog) antara Pemerintah desa dengan peserta tentang isu-isu atau permasalahan serta pemecahan masalah. Ketiga, Isi/Kualitas Program: Kualitas hasil musrenbang rendah dan kurang sistematis. hanya berisi rekapitulasi, yang berisi kegiatan dan dana yang dibutuhkan. Dari segi tujuan, cara untuk merealisasi kegiatan -kegiatan dan waktu secara rinci tidak dijelaskan. Keempat,Stakeholders: Stakeholders tidak terwakili secara menyeluruh dalam Musrenbang, haya diikuti oleh BPD, Kepala Desa, Ketua LPMD, Ketua Tim Penggerak PKK dan Tokoh Masyarakat yang mereka kenal. Organisasi kepentingan seperti LSM, organisasi kelembagaan lokal, tokoh adat atau organisasi privat tidak masuk sebagai peserta Musrenbang (Tresiana \& Duadji, 2016).

(Zakiah, 2019) Berdasarkan hasil Analisis dalam Upaya-upaya yang dilakukan untuk mengatasi hamabatan-hambatan dalam Proses Musyawarah Perencanaan Pembangunan di Desa Tonrongnge Kecamatan Baranti Kabupaten Sidenreng Rappang sebagai berikut:

1. Pemerintah desa mengadakan sosialisasi kepada masyarakat dan stakeholder sehingga dapat memahami proses musyawarah perencanaan pembangunan. Selain itu,

2. Meningkatkan sumberdaya manusianya melalui pelatihan dan pembinaan agar aparatur desa, stakeholder, kelompok perempuan dan masyarakat bekerja sama dengan baik dalam membangun daerahnya.

3. untuk mengatasi terbatasnya dana maka pemerintah desa harus meningkatkan pendapat asli desa dari Bumdes, swadaya masyarakat dan pendapatan desa lainnya.

4. Mengajukan kembali program/kegiatan skala prioritas pembangunan tahun sebelumnya tidak terealisasi. Dengan mengharapkan akan terealisasi pada tahun yang akan datang sehingga masyarakat dapat merasakan manfaat dari program/ 
kegiatan hasil Musyawarah perencanaan Pmebangunan di Desa Kertayasa Kecmatan Cijulang Kabupaten Pangandaran

5. Dengan mengkaji potensi yang ada di wilayah desa secara musyawarah mufakat untuk menentukan skala prioritas pembangunann sesuai dengan kebutuhan masyarkat.

6. Dalam tingkat kepuasan masyarakat aparatur desa memberikan pengertian bahwa tidak semua kebutuhan dan keinginan masyarakat dapat direalisikan secara bersamaan dalam persatu tahun.

\section{KESIMPULAN}

keberhasilan atau kemajuan desa ditandai dengan tersedianya sarana prasarana yang baik sehingga segala aktifitas yang mereka lakukan berjalan dengan baik dan lancar. Karena itu, Musrenbang desa sebagai salah satu tugas dan kewenangan desa selaku unit otonom, merupakan proses yang penting bagi desa untuk membangun desanya sendiri. Akan tetapi forum Musrenbang di desa Tonrongnge terbukti telah mengandung sejumlah kelemahan di hampir semua levelnya. Adapun dari hasil analisis penulis beberapa kelemahan pemerintah desa dalam forum Musrembang; pertama, aspirasi masyarakat yang ditampung dalam musyawarah perencanaan pembangunan tidak selalu dapat direalisasikan oleh pemerintah desa. Kedua, mendominasinya skala prioritas pembangunan fisik, seperti infrastruktur pembangunan jalan penghubung antar dusun sedangkan dalam pembangunan ekonomi masih kurang. Ketiga, Partisipasi perempuan dalam proses musyawarah perencanaan pembangunan kurang dilibatkan. Hal ini dapat di sebabkan karena masih adanya anggapan bahwa dalam perencanaan pembangunan itu adalah kegiatan untuk laki-laki. Keempat, kurangnya pemahaman dalam mengidentifikasi suatu permasalahan yang ada dilingkungan sesuai dengan apa yang masyarakat butuhkan. Kelima, Kebijakan yang direncanakan dalam proses musyawarah perencanaan pembangunan belum tepat sasaran. Hal ini diketahui karena hasil dari musyawarah perencanaan pembangunan setiap tahunnya tidak terealisasi. Sehingga output kebijakan belum dirasakan masyarakat. Hal ini dapat di terjadi karena kurangnya pemahaman dalam mengidentifikasi suatu permasalahan yang ada dilingkungan sesuai dengan apa yang masyarakat butuhkan.

\section{DAFTAR PUSTAKA}

Afiyanti, Y. (2014). Penggunaan Literatur Dalam Penelitian Kualitatif. Jurnal Keperawatan Indonesia, 9(1), 33-35. https://doi.org/10.7454/jki.v9i1.157

Hatta, U. B. (2014). Program Fisik Musyawarah Perencanaan Pembangunan (Musrenbang) di Kelurahan Pasar Rantau Panjang. 1-10.

Irwan, Latif, A., Sofyan, Mustanir, A., \& Fatimah. (2019). gaya kepemimpinan, kinerja aparatur sipil negara dan partisipasi masyarakat terhadap pembangunan di kecamtan kulo kabupaten sidenreng rappanh. Jurnal MODERAT, 5(1), 32-43.

Latif, A., Irwan, \& Mustanir, A. (2019). Analisis Kepemimpinan Terhadap Optimalisasi Masyarakat Pada Perencanaan Pembangunan Di Enrekang. Jurnal Analisis Kebijakan Dan Pelayanan Publik, 5(2), 1-20. https://doi.org/10.20956/xxxxxx

Latif, A., Mustanir, A., \& Irwan, I. (2019). Pengaruh Kepemimpinan Terhadap Partisipasi Masyarakat Pada Perencanaan Pembangunan. JAKPP (Jurnal Analisis Kebijakan \& Pelayanan Publik), 144-164. 
https://oi.org/10.31947/jakpp.v1 i2.7977

Mustanir, A., \& abadi, partisan. (2017). Partisipasi masyarakat dalam musyawarah rencana pembangunan di kelurahan kanyuara kecamatan watang sidenreng kabupaten sidenreng rappang. Jurnal Politik Profetik, 5(2).

Mustanir, A., Fitriani, S., Adri, K., Nurnawati, A. A., \& Goso, G. (2020). Sinergitas Peran Pemerintah Desa dan Partisipasi Masyarakat Terhadap Perencanaan Pembangunan di Kabupaten Sidenreng Rappang (The Synergy of Village Government's Role and Community Participation in the Process of Development Planning in Sidenreng Rappang D. Journal of Government Science (GovSci), 2, 84-108.

Mustanir, A., Madaling, Uceng, A., M, N., Barisan, Dewi, \& Andriani. (2019).

Karakteristik Kepemimpinan Lurah Terhadap Partisipasi Masyrakat Dalam Musyawarah Perencanaan Pembangunan Di Kelurahan Duampanua Kecamatan Banrati Kabupaten Sidenreng Rappang. Jurnal Ilmiah Clean Government, 2(2), 145-172.

Mustanir, A., \& Razak, M. R. R. (2017). Nilai Sosial Budaya Pada Partisipasi Masyarakat Etnik Towani Tolotang Dalam Musyawarah Rencana Pembangunan. Prosiding Konferensi Nasional Ke-6 Asosiasi Program Pascasarjana Perguruan Tinggi Muhammadiyah Aisyiyah (APPPTMA), September, 1-7. http//asosiasipascaptm. or.id/index.php/publikasi/prosiding-konferensi-nasionalappptma-ke-6

Mustanir, A., \& Rusdi, M. (2018). Participatory Rural Appraisal ( PRA ) Sebagai Sarana Dakwah Muhammadiyah Pada Perencanaan Pembangunan Di Kabupaten Sidenreng Rappang. 03, 1-9.

Mustanir, A., Sellang, K., Ali, A., Madaling, \& Mutmainna. (2018). Peranan Aparatur Pemerintah Desa Dan Partisipasi Masyarakat Dalam Musywarah Perencanaan Pembangunan Di Desa Tonrongnge Kecamatan Baranti Kabupaten Sidenreng Rappang. Jurnal Ilmiah Clean Government, 2(1), 67-84.

Mustanir, A., \& Yasin, A. (2018). Transect Pada Perencanaan Pembangunan Partisipatif. Jurnal Ilmiah Ilmu Administrasi Publik, 8(2), 21-31.

Tresiana, N., \& Duadji, N. (2016). Kegagalan pemaknaan 'Lembaga Musawarah Perencanaan dan Pembangunan Desa"dalam mewujudkan deepening democracy. Masyarakat, Kebudayaan Dan Politik, 29(4), 191. https://doi.org/10.20473/mkp.v29i42016.191-203

Zakiah, E. (2019). Evaluasi Proses Musyawarah Perencanaan Pembangunan Di Desa Kertayasa Kecamatan Cijulang Kabupaten Pangandaran. Angewandte Chemie International, 63-69. 